\title{
DIREITOS HUMANOS FUNDAMENTAIS NA ERA TECNOLÓGICA: REFLEXÕES SOBRE O PÓS-HUMANISMO
}

Marcelo Benacchio

Doutor e Mestre em Direito pela Pontifícia Universidade Católica de São Paulo. Professor do Mestrado em Direito e Graduação da Universidade Nove de Julho. Professor Titular da Faculdade de Direito de São Bernardo do Campo. Juiz de Direito em São Paulo.

Quella Rocha Carmona dos Santos

Doutoranda em Direito pela Pontifícia Universidade Católica de São Paulo. Mestre em Justiça, Empresa e Sustentabilidade pela Universidade Nove de Julho. Advogada.

\section{Resumo}

A presente pesquisa busca destacar o cenário da tecnologia pós-moderna que possibilita manipulaçóes da natureza humana e seus reflexos sobre os direitos humanos fundamentais. Objetiva-se com este estudo refletir sobre o potencial tecnológico da pósmodernidade em face dos direitos afirmados ao longo do tempo, contrapondo o novo ao tradicional. A técnica de pesquisa utilizada é a bibliográfica e a abordagem se dá pelos métodos dedutivo e indutivo. Aderindo à obra Biotecnología y Posthumanismo coordenada por Jesús Ballesteros e Encarnación Fernández para fundamentar a temática proposta. Cumpre ressaltar a princípio que as ameaças à dignidade da pessoa humana ganham nova roupagem. Dessa forma, ao passo que surgem novas ameaças, a ciência do Direito deve incorporar novas ferramentas para cumprir com seu papel de tutelar a sociedade.

\section{Palavras-chave}

Direitos Humanos Fundamentais; Dignidade da Pessoa Humana; Tecnologia; Pós -Humanismo; Ética.

\section{Resumen}

Esta investigación pretende destacar el panorama de la tecnología posmoderna que permite la manipulación de la naturaleza humana y sus efectos en los derechos humanos fundamentales. Objetiva con este estudio reflexionar sobre el potencial tecnológico de la posmodernidad frente a los derechos afirmados con el tiempo, en oposición de lo nuevo al 
tradicional. La técnica de investigación utilizada es la literatura y el enfoque si da por medio de los métodos deductivos e inductivos. Se recurre a la obra Biotecnología y Posthumanismo coordinada por Jesús Ballesteros y Encarnación Fernández para apoyar el tema propuesto. Cabe señalar que las principales amenazas a la dignidad humana adquieren nuevo disfraz. Así, mientras surgen nuevas amenazas la ciencia del derecho debe incorporar nuevas herramientas para cumplir con su papel de proteger a la sociedad.

\section{Palabras clave}

Derechos Humanos Fundamentales; Dignidad Humana; Tecnología; Post-humanismo; Ética.

\section{Introdução}

A presente pesquisa busca destacar o cenário da tecnologia pós-moderna que possibilita manipulaçóes da natureza humana e seus reflexos sobre os direitos humanos fundamentais.

Diante de tecnologias que podem interferir na natureza humana com intento de promover a perfeição e por termo à deficiência em detrimento ao princípio da dignidade da pessoa humana, pergunta-se: é possível impor limites a essas práticas por meio do ordenamento jurídico ou seria momento de repensar a esfera de proteção jurídica humana?

A resposta a essa pergunta requer reflexões interdisciplinares. Todavia, a princípio é possível pensar que o atual cenário tecnológico deve ter como limite a inviolabilidade da dignidade da pessoa humana e respectivamente dos valores de liberdade, igualdade e solidariedade. Nesse contexto, vale ainda considerar a ética como alicerce para alargamento dos direitos humanos fundamentais em termos de um novo direcionamento do agir tecnológico.

Objetiva-se com este estudo refletir sobre o potencial tecnológico da pós-modernidade em face dos direitos afirmados ao longo do tempo, contrapondo o novo ao tradicional. Para tanto, inicia-se pelos conceitos de direitos humanos fundamentais, na sequência aborda-se a ideia de proteção da dignidade da pessoa humana na era tecnológica. Desse ponto, passa-se a tratar sobre o pós-humanismo ${ }^{1}$ sob uma perspectiva de releitura dos direitos humanos fundamentais.

1 Terminologia adotada na obra referência deste estudo (Biotecnología y Posthumanismo. Jesús Ballesteros e Encarnación Fernández (Coord.). 1. ed. Editorial Aranzadi, 2007. Tal expressão remete à ideia do atual período histórico pós-moderno em que o desenvolvimento tecnológico paradigmático permite no campo da biotecnologia a busca da perfeição humana. Dessa forma, os processos naturais aos poucos se tornam artificiais ou se misturam em uma escala em que tudo parece benéfico ao homem. Todavia, 
A presente pesquisa justifica-se pela importância de aproximar a ciência do direito à realidade contemporânea do desenvolvimento tecnológico, bem como, em razão da necessária prevalência dos direitos humanos fundamentais em face das novas ameaças à dignidade.

A técnica de pesquisa utilizada é a bibliográfica e a abordagem se dá pelos métodos dedutivo e indutivo. Aderindo à obra Biotecnología y Posthumanismo coordenada por Jesús Ballesteros e Encarnación Fernández para fundamentar a temática proposta.

\section{Direitos Humanos Fundamentais}

Apesar da existência de vários registros históricos acerca da proteção dos direitos do homem a partir do século VIII a. C., é relativamente recente a noção do reconhecimento dos seres humanos como categoria geral ${ }^{2}$. Os Direitos Humanos temporalmente nascem com a modernidade sob influência do iluminismo, alicerce ideológico das revoluçóes burguesas do século XVIII na compreensão dos seres humanos como iguais e livres.

Os Direitos Humanos são considerados direitos históricos, conquistados por meio de lutas para afirmação e ampliação dos direitos garantidores do bem-estar humano ao longo da história.

No contexto do Estado de Direito a preocupação predominante era com os direitos de liberdade frente o poder do Estado, sendo que, na sequência, as carências percebidas e reivindicaçóes são relativas aos direitos de igualdade. Nessa linha de desenvolvimento social tais exigências adquirem novas razóes passando a ser referentes aos direitos de solidariedade na conjuntura do Estado Democrático e Social de Direito.

Essa evolução pode ser compreendida por meio do fenômeno da "dinamogenesis"3 dos direitos humanos que consiste no nascimento e desenvolvimento dinâmico do direito de acordo com as necessidades apresentadas em cada momento da história.

Vladmir Oliveira da Silveira e Maria Mendez Rocasolano compreendem que no mundo axiológico, os valores adquirem novos contornos, que significa a adaptação dos originais às novas particularidades sociais. ${ }^{4}$ Portanto, com o desenvolvimento ou nascimento de novos valores em razão das circunstâncias históricas, manifesta-se na sociedade, a necessidade de direitos específicos que protejam tais valores.

cabe indagar juridicamente: quais são os limites que a tecnologia não deve ultrapassar no que se refere à manipulação da natureza humana, sob pena de ferir os valores consagrados de direitos humanos fundamentais?

2 COMPARATO, Fábio Konder. A afirmação histórica dos direitos humanos. São Paulo: Saraiva, 2008, p. 12.

3 SILVEIRA, Vladmir Oliveira da e ROCASOLANO, Maria Mendez. Direitos Humanos: conceitos, significados e funçóes. São Paulo: Saraiva, 2010.

4 Ibidem., p. 194. 
Com efeito, Pérez Luño define Direitos Humanos como:

um conjunto de faculdades e instituiçóes que, em cada momento histórico, concretizam as exigências da dignidade, da liberdade e das igualdades humanas, as quais devem ser reconhecidas positivamente pelos ordenamentos jurídicos a nível nacional e internacional. ${ }^{5}$

Segundo o autor, a definição proposta busca unir as grandes dimensóes que integram a noção geral dos direitos humanos, ou seja, a exigência jusnaturalista em relação a sua fundamentação e as técnicas de positivação e proteção que possibilitam seu exercício ${ }^{6}$.

Vladmir Oliveira da Silveira e Maria Mendez Rocasolano ${ }^{7}$ sustentam que o principal fundamento dos direitos humanos é a dignidade da pessoa humana, sendo que, a partir do final da Primeira Guerra Mundial, em 1918, a expressão direitos humanos, vinculouse ao valor da dignidade da pessoa humana, sob uma concepção de viver, conviver e futuro dos indivíduos dentro da comunidade.

Considerando que os direitos humanos sáo o resultado de uma evoluçáo ao longo da história, que se deu por meio de lutas para conquistas de direitos, Norberto Bobbio afirma que:

(...) os direitos do homem, por mais fundamentais que sejam, são direitos históricos, ou seja, nascidos em certas circunstâncias, caracterizadas por lutas em defesa de novas liberdades contra velhos poderes, e nascidos de modo gradual, não todos de uma vez e nem de uma vez por todas. ${ }^{8}$

Portanto, os direitos humanos aos poucos foram afirmados e de tempo em tempo são ampliados para combater o poder, atender as novas carências humanas e ainda concretizar sua dignidade.

Em suma, os direitos humanos se desenvolvem em face de novas ameaças à dignidade da pessoa humana.

Nessa linha, cumpre ressaltar que em um primeiro momento houve a conquista de direitos individuais relacionados aos valores de liberdade. Na sequência, se reconhece que esses direitos não são suficientes para assegurar a dignidade da pessoa humana, assim, ocorre à complementação com os direitos coletivos fundados no valor da igualdade. Após tais conquistas, a sociedade em constante evolução se modifica passando a ter novas carências

5 Derechos Humanos, Estado de Derecho y Constitución. Madrid: Tecnos, 2010. p. 50, tradução nossa. (un conjunto de facultades e instituciones que, en cada momento histórico, concretan las exigencias de la dignidad, la libertad y la igualdad humanas, las cuales deben ser reconocidas positivamente por los ordenamientos jurídicos a nivel nacional e internacional.).

6 Ibidem. p. 53.

7 Direitos Humanos: conceitos, significados e funçóes. São Paulo: Saraiva, 2010. p. 217.

8 A Era dos Direitos. Traduçáo de Carlos Nelson Coutinho. Rio de Janeiro: Elsevier, 2004. p. 5. 
de direitos, dos quais, se destacam o direito ao desenvolvimento e ao meio ambiente, inclusive para as futuras geraçóes, sob a perspectiva do valor de solidariedade.

Importa, pois destacar a teoria do poder como basilar à formação dos direitos humanos. Vladmir Oliveira da Silveira e Maria Mendez Rocasolano argumentam que:

O desenvolvimento da noção de direitos humanos configura uma história de confrontação e de luta incessante pelos valores da humanidade, em que o poder imposto aos homens e sua organizaçáo em comunidades, povos e Estados, foi se perdendo nas batalhas sob a ordem da liberdade, igualdade e solidariedade (fraternidade) dos seres humanos, que se rebelaram guiados pelas luzes da razão e dos valores e sentimentos compartilhados. ${ }^{?}$

Esses movimentos de lutas para o reconhecimento e proteção de direitos inerentes à dignidade da pessoa humana surgiram contra poderes que operavam em desfavor da sociedade e até mesmo da humanidade. Tratava-se da imposição da vontade arbitrária daqueles que detinham o poder sobre a coletividade.

Tendo em vista que os direitos humanos nascem para tutelar as necessidades humanas em uma dimensão não apenas individual, mas também coletiva relacionada ao bem comum. Esses direitos, entendidos como inerentes ao homem passam a ser positivados em declaraçóes universais e regionais de direitos, bem como, em âmbito interno, nas constituiçóes estatais.

Para Norberto Bobbio "o reconhecimento e a proteção dos direitos do homem são a base das constituiçóes democráticas". ${ }^{10}$ Portanto, os direitos humanos passam, de forma crescente, a fazer parte das constituiçóes como resultado do reconhecimento desses direitos no âmbito dos Estados.

O autor sustenta que a Declaração Universal de Direitos Humanos é apenas o início de um longo processo de desenvolvimento dos direitos humanos, pois “os direitos do homem nascem como direitos naturais universais, desenvolvem-se como direitos positivos particulares, para finalmente encontrarem sua plena realizaçáo como direitos positivos universais". ${ }^{11}$

Os direitos humanos têm suas origens ligadas ao direito natural do homem e ao se desenvolverem no decorrer da história, tornam-se direito positivado, tanto em escala universal quanto estatal. Destaca-se, no entanto, que a universalidade ${ }^{12}$ dos direitos

9 Direitos Humanos: conceitos, significados e funçóes. São Paulo: Saraiva, 2010. pp. 21-22.

10 A Era dos Direitos. Traduçáo de Carlos Nelson Coutinho. Rio de Janeiro: Elsevier, 2004. p. 203.

11 Ibidem., p. 30.

12 Flávia Piovesan argumenta que o ponto de partida dos relativistas é o coletivismo, sendo que o indivíduo é percebido apenas como parte integrante da sociedade. Diversamente, sob a ótica dos universalistas, o 
humanos no âmbito do multiculturalismo estatal pode sofrer diferentes interpretaçóes, mas ainda que as culturas se diferenciem a essencialidade e natureza desses direitos não mudam, pois, em suma, são voltados à proteção da vida, liberdade, igualdade e dignidade da pessoa humana.

Nesse sentido argumenta Norberto Bobbio que após a Declaraçáo Universal é possível ter a certeza histórica de que "toda a humanidade - partilha alguns valores comuns; e podemos, finalmente, crer na universalidade dos valores". ${ }^{13}$

A Declaraçáo Universal de Direitos Humanos é o documento que introduz a positivaçáo dos direitos humanos. Essa declaração é considerada a mais importante, pois dela surgem as demais declaraçóes internacionais de direitos do homem, nas esferas universal e regional. Assim, a partir desse marco inicial, as constituiçóes em âmbito estatal passam também a reconhecer e positivar os direitos humanos.

O reconhecimento e positivação dos direitos humanos nas constituições dos Estados pode ser entendido como movimento de constitucionalismo dos direitos humanos, ou seja, positivam-se esses direitos a partir de um exercício mútuo de constitucionalização dos diretos humanos e internacionalizaçáo dos direitos fundamentais.

Os direitos fundamentais são um conjunto de direitos e garantias previstos nas constituiçôes que devem ser interpretados e refletidos em todo o ordenamento jurídico infraconstitucional.

Dessa forma, os direitos e garantias fundamentais positivados constitucionalmente devem promover em âmbito interno a prevalência da dignidade da pessoa humana, como parte de sua responsabilidade perante a ordem internacional, pois paralelo ao ordenamento jurídico nacional há os sistemas de proteçấo universal e regional que atuam como poder subsidiário à atuação estatal para assegurar a observância dos direitos humanos fundamentais.

Pérez Luño ao tratar das noçóes de direitos fundamentais e Estado de Direito ressalta que "os direitos fundamentais representam, por sua vez, os princípios inspiradores de toda a política estatal. Pelo que cumprem uma missão de fundamento e limite de todas as normas que organizam o funcionamento dos poderes públicos" (...). ${ }^{14}$

primado é o individualismo, portanto, o ponto de partida é o indivíduo, sua liberdade e autonomia, para entấo se chegar à coletividade. Sustenta ainda que "os instrumentos internacionais de direitos humanos são claramente universalistas, uma vez que buscam assegurar a proteção universal dos direitos e liberdades fundamentais (...) para os universalistas o fundamento dos direitos humanos é a dignidade humana, como valor intrínseco à própria condição humana”. Direitos Humanos e o Direito Constitucional Internacional. 13. ed. São Paulo: Saraiva, 2012. pp. 216-218.

13 A Era dos Direitos. Tradução de Carlos Nelson Coutinho. Rio de Janeiro: Elsevier, 2004. p. 28.

14 Derechos Humanos, Estado de Derecho y Constitución. Madrid: Tecnos, 2010. p. 219, tradução nossa. (los derechos fundamentales encarnan, a su vez, los principios inspiradores de toda la política 
Os direitos humanos ingressaram nas primeiras Constituiçóes escritas enquanto direitos fundamentais como garantia de realização da dignidade humana sendo expandidos na concretização de valores como igualdade, liberdade e justiça legitimando o Estado Democrático e Social de Direito ${ }^{15}$.

Os direitos fundamentais são caracterizados pela abertura dos conteúdos, funções, e formas de proteção permitindo sua defesa em face de ameaças e perigos que possam surgir no curso do tempo com as mudanças operadas no meio social.

Ressaltando esses aspectos Cristina Queiroz ${ }^{16}$ afirma:

Não existe um numerus clausus de dimensóes de tutela, do mesmo modo que não existe um numerus clausus dos perigos. Daí a origem da expressão "protecção dinâmica dos direitos fundamentais", utilizada pelo Tribunal Constitucional Federal alemão, a que corresponde uma tutela "flexível, móvel e aberta" desses direitos no seu conjunto. Konrad Hesse fala a propósito, de uma "compreensão alargada dos direitos fundamentais".

Logo, diante de tais consideraçóes é importante ressaltar as disposiçóes de direitos fundamentais abarcadas pela Constituição da República Federativa do Brasil de 1988 que fundamentam juridicamente a proteção e bem-estar da sociedade e dão base às reflexóes da presente pesquisa no que se refere aos limites da intervenção tecnológica na natureza humana.

$\mathrm{O}$ artigo $1^{\circ}$, III da Constituição traz, entre outros, a dignidade da pessoa humana como princípio fundamental do Estado, nos seguintes termos: "A República Federativa do Brasil, formada pela união indissolúvel dos Estados e Municípios e do Distrito Federal, constitui-se em Estado Democrático de Direito e tem como fundamentos: III - a dignidade da pessoa humana”.

Nessa linha de proteção da dignidade da pessoa humana, a Constituição ao estabelecer os direitos e garantias fundamentais, prevê no artigo $5^{\circ}$, entre as demais previsóes, a inviolabilidade dos direitos à vida, liberdade, igualdade e segurança.

Assim sendo, pode-se afirmar que o ordenamento jurídico pátrio tem como princípio básico a proteção da dignidade da pessoa humana. A proteção constitucional possibilita, ainda, a ampliação da proteção e criação de novos direitos como é o caso do artigo $5^{\circ}$, parágrafo $2^{\circ}$, entendido como clausula de abertura. No entanto, a grande dificuldade é sempre como dar efetividade aos preceitos que visam a proteçáo humana, sendo certo,

estatal. Por lo que cumplen una misión de fundamento y límite de todas las normas que organizan el funcionamiento de los poderes públicos.).

15 SARLET, Ingo Wolfgang. A eficácia dos direitos fundamentais. Porto Alegre: Livraria do Advogado, 2006, p. 76.

16 Direitos Fundamentais. Coimbra: Coimbra, 2010, p. 62. 
que para fortalecimento dessa proteção é essencial a complementação entre o direito interno e o direito internacional de proteção dos direitos humanos fundamentais.

\section{A Proteção da Dignidade da Pessoa Humana na Era Tecnológica}

A chamada era tecnológica corresponde ao atual período histórico da pós-modernidade $^{17}$ em que as descobertas e possibilidades tecnológicas são paradigmáticas. Desta feita, cumpre refletir sobre a vertente tecnológica que tem poder para interferir na natureza humana, bem como sobre os limites que devem ser preservados ou mesmo estabelecidos em prol da proteção da dignidade da pessoa humana.

Considerando pois, a pessoa humana, Rui Nunes defende que:

(...) a dignidade confere-lhe o direito de ser sempre considerado como sujeito, em si mesmo, com uma finalidade própria, dotado de liberdade no plano ético, não podendo nunca ser considerado como um objeto do desejo ou da manipulação de terceiros. Esta liberdade ética fundamental implica que a ciência concorra sempre para melhorar as condiçóes de existência da humanidade respeitando a identidade do sujeito e a da espécie a que pertence. Esta linha de pensamento está na base da edificação daquilo que hoje conhecemos e valorizamos por direitos humanos fundamentais..$^{18}$

Nesse sentido, cumpre afirmar que a dignidade confere à pessoa o direito de ser um fim em si mesma e não um objeto passível de manipulaçóes. Assim, cabe à ciência e a tecnologia contribuir para o bem-estar humano, bem como assegurar a inviolabilidade da identidade do sujeito e da sua espécie sob uma perspectiva dos direitos de liberdade, igualdade e solidariedade.

Conforme o autor, essa linha de pensamento se funda no respeito aos direitos humanos fundamentais amplamente consagrados.

Em termos de tecnologia, importa mencionar Francesco di Ciommo ao expor que para se chegar ao desenvolvimento da tecnologia houve primeiro a evolução da técnica. A técnica, a princípio, era o instrumento essencial para a sobrevivência do homem, sendo que, o homem era o sujeito manipulador da técnica" 19 . Para o autor "a técnica, de instrumento

17 O atual modelo de sociedade pós-moderna, é caracterizado pela leveza das estruturas econômicas, sociais e das relações humanas, pois a exigência do momento é eficiência e mobilidade. Nessa linha, prevalece também o individualismo e a busca incessante pelos fins independentemente dos meios. Essa realidade, portanto, dificulta a criação do diálogo entre técnica e crítica como um meio para projetar o futuro tecnológico. Sobre pós-modernidade, ver: BAUMAN, Zygmunt. Modernidade Líquida. Tradução de Plínio Dentzien. Rio de Janeiro: Zahar, 2001.

18 Gene Ética. Coimbra: Almedina, 2013. p. 27.

19 Evoluzione tecnologica e regole di responsabilitá civile. Napoli: Edizioni Scientifiche Italiane, 2003. 
a disposição do homem, tornou-se assim o seu ambiente; de meio para satisfazer as suas exigências naturais, tornou-se, em alguns aspectos, produto e, por outros, fonte de sempre novas necessidades e problemas". ${ }^{20}$

A técnica, portanto, era o método para o homem desempenhar seu trabalho, ou seja, o caminho para chegar a determinado fim. No entanto, com a evolução tanto da ciência quanto da técnica chega-se à tecnologia que, por sua vez, passa a ocupar o lugar de destaque da técnica, agora também como fim.

Desta feita, a lógica se inverte, pois o objeto passa a manipular o sujeito. Nessa linha, aponta Francesco di Ciommo que a tecnologia e não mais a atividade humana preside a sua própria criação ao ditar os ritmos e dimensóes do desenvolvimento tecnológico futuro e, em última análise, da própria existência do indivíduo. ${ }^{21}$

O significado da técnica, enquanto instrumentação nas mãos do homem para satisfazer suas necessidades naturais, era completamente absorvido pelo fim específico a que esta era destinada a perseguir. Todavia, o aumento quantitativo e imensurável da tecnologia na atualidade, possibilita o alcance de qualquer fim, o que faz mudar qualitativamente o cenário, pois não é mais o fim ético ou prático a condicionar a pesquisa científica, mas sim os resultados da pesquisa a condicionar os fins. ${ }^{22}$

De forma concisa, o autor entende que nesta era, a tecnologia produz sempre novos resultados universalmente aplicáveis, o que a torna autorreferencial e independente. Portanto, não existem valores, ideologias, nem ética, capazes de condicionar a tecnologia, uma vez que, esta nega qualquer tradição e, em seu rápido avanço se coloca como elemento de ruptura com o cenário preexistente, queimando etapas e alcançando objetivos que muitas vezes a ciência não visa. ${ }^{23}$

Logo, a revolução tecnológica reformulou as relaçôes do ser humano com os demais seres humanos, as relaçóes entre o ser humano e a natureza, bem como as relaçóes do ser humano para consigo mesmo, afetando diretamente as esferas dos direitos e liberdades. ${ }^{24}$

As novas tecnologias da informação e da comunicação conduziram a humanidade para um novo patamar, revelando a insuficiência da solução dos novos desafios pela projeção do passado ao futuro em conformidade à compreensão iluminista da codificação do Direito.

20 Ibidem. p. 16, tradução nossa. (La tecnica, da strumento a disposizione dell'uomo, è così diventata il suo ambiente; da mezzo per soddisfare le sue esigenze naturali, è diventata, per certi versi, prodotto e, per altri, fonte di sempre nuovi bisogni e problemi.).

21 Ibidem. mesma página.

22 Ibidem. p. 18.

23 Ibidem. p. 20.

24 PÉREZ LUÑO, Antonio-Henrique. Los Derechos Humanos ante las Nuevas Tecnologías. In: Nuevas Tecnologías y Derechos Humanos. PÉREZ LUÑO, Antonio-Henrique. Valencia: Tirant lo blanch, 2014. p. 18. 
Há várias situaçóes na atualidade sem paralelo no passado, a exemplo da engenharia genética e tantas outras situaçóes semelhantes reveladoras das dificuldades do Direito em apresentar um paradigma adequado e seguro de solução. A pós-modernidade não permite as "certezas" da modernidade.

Assim, a aplicação da tecnologia no âmbito da reprodução assistida, com a maternidade de substituição, tornou incerta a antes indiscutível máxima romana - mater semper certa est, pater autem incertus - ante a possibilidade de não coincidência entre a gestação e a filiação nessa hipótese.

Considerando tais exemplos, cumpre considerar que o desafio da atualidade é a compatibilização entre os aprendizados do passado que repercutiram na Declaração Universal dos Direitos Humanos e o futuro acerca da evolução da proteção internacional dos Direitos Humanos ${ }^{25}$, porquanto a pós-modernidade com seu conjunto de tecnologias revolucionárias impóe a necessidade de se repensar a condição humana. ${ }^{26}$

\section{Reflexões sobre o Pós-Humanismo e uma Proposta de Releitura dos Di- reitos Humanos Fundamentais}

Conforme abordado anteriormente o avanço tecnológico produziu diversas mudanças e novos resultados nos espaços sociais com reflexo na ciência do direito. Diante desse cenário vale repensar o papel e abrangência dos direitos humanos fundamentais frente a aplicação da biotecnologia com intuito de manipular a natureza humana.

Nicolau Sevcenko, a respeito da corrida tecnológica do século XXI, afirma que:

A aceleração das inovações tecnológicas se dá agora numa escala multiplicativa, uma autêntica reaçáo em cadeia, de modo que em curtos intervalos de tempo o conjunto do aparato tecnológico vigente passa por saltos qualitativos em que a ampliação, a condensação e a miniaturização de seus potenciais reconfiguram completamente o universo de possibilidades e expectativas, tornando-o cada vez mais imprevisível, irresistível e incompreensível. ${ }^{27}$

O autor destaca a velocidade do avanço tecnológico, tendo em vista que em sua rápida marcha produz resultados que obscurecem a apreensão dos reais efeitos sobre a

25 LAUREN, Paul Gordon. The Evolution of International Human Rights. Philadelphia: University of Pennsylvania, 2003, p. 281.

26 DONAS, Javier Bustamante. Los Derechos Humanos de Cuarta Generación y sus Implicaciones en la Sociedad Contemporánea. In: Los Derechos Humanos en Internet. DONAS, Javier Bustamante; et al. Madrid: Cideal, 2012. p. 13.

27 A corrida para o Século XXI - No loop da montanha-russa. São Paulo: companhia das Letras, 2001. pp. 16-17. 
dignidade da pessoa humana. Destarte, diante desse cenário a sociedade segue como em um loop de montanha russa, cujos movimentos causam a sensação de imprevisível, irresistível e incompreensível. ${ }^{28}$

Nesse linha de celeridade da ciência e tecnologia Michael J. Sandel sustenta que:

Quando a ciência avança mais depressa do que a compreensão moral, como é o caso de hoje, homens e mulheres lutam para articular seu mal -estar. Nas sociedades liberais, buscam primeiro a linguagem baseada nos conceitos de autonomia, justiça e direitos humanos. Essa parte de nosso vocabulário moral, no entanto, não nos equipou para abordar temas mais difíceis colocados pelas práticas de clonagem, crianças projetadas e engenharia genética. É por isso que a revolução genômica induziu a uma espécie de vertigem moral ${ }^{29}$.

Portanto, quando a ciência e tecnologia avança mais rápido que a compreensão moral e novas técnicas são postas em prática, as quais envolvem a manipulação da própria natureza humana pelo homem, o recurso aos conceitos de justiça e direitos humanos afirmados ao longo do tempo não oferece uma resposta às inquietaçóes geradas.

Nesse sentido, cumpre destacar as raízes do pós-humanismo que se volta a exaltação da tecnologia como libertação do humano. O pós-humanismo se funda no fim do humanismo $^{30}$ por meio da negação à deficiência moral, física e da diferença sexual. ${ }^{31}$

Tendo em vista o objeto deste estudo, cumpre destacar a negação da deficiência física que consiste, entre outros, na licitude da eutanásia e eugenia em busca de um corpo perfeito por meio de sua total manipulação. Nessa linha, ressalta-se a criação do útero artificial para vigilância do embrião, assim como a ideia de imortalidade. ${ }^{32}$

Jesús Ballesteros expõe que não aceitar a deficiência humana é própria da ideologia puritana que persegue a perfeição e abomina a deficiência. O puritanismo admite somente a dignidade daqueles que são considerados virtuosos. A eutanásia e a eugenia são uma espécie de puritanismo da saúde que busca acabar com a deficiência física e com os

28 Ibidem.

29 Contra a perfeição: ética na era da engenharia genética. Tradução de Ana Carolina Mesquita. 1. ed. Rio de Janeiro: Civilização Brasileira, 2013. p. 22.

30 A chave do humanismo é o princípio de que todo ser humano tem uma dignidade inalienável e, por tanto, não pode ser tratado em nenhum caso como simples meio, somente como fim. O humanismo exige a exclusão da violência e dos tratos degradantes, como a tortura contra o ser humano, assim como sua instrumentalização. BALLESTEROS, Jesús. Biotecnología, biolítica y posthumanismo. In: Biotecnología y Posthumanismo. Jesús Ballesteros; Encarnación Fernández. (Coord.). 1. ed. Editorial Aranzadi, 2007. p. 26.

31 Ibidem. p. 27.

32 Ibidem. mesma página. 
enfermos. Pois, convém eliminar os homens naturais como se eliminava os hereges e os ímpios a fim de se chegar à pureza física. ${ }^{33}$

Com efeito, o autor aduz que a biotecnologia atualmente conta não só com a pretensão de lutar contra as enfermidades (vertente lícita), mas também com a pretensão de superar a espécie humana por meio de duas vias: a manipulação genética somática ou germinal que afeta o corpo ou a inteligência artificial que afeta o cérebro. Em ambas vias, se trata de reduzir a realidade humana a simples informação, cedendo às exigências da tecnociência ${ }^{34}$ e do mercado, tendo em vista que tudo é comerciável e ou controlável. ${ }^{35}$

O capitalismo invade, portanto, as esferas pública e privada, pois o poder do capital influencia as políticas estatais, as ações dos entes particulares e ainda o comportamento humano. Dessa forma, em termos de capitalismo e mercado, Pietro Barcelona sustenta como premissa que o projeto ocidental garante o máximo de "privatização do mundo" reduzindo a esfera pública às regras do mercado; afirmando assim a indiferença e a solidão na dimensão propriamente existencial da vida ${ }^{36}$.

Nesse sentido, pode-se entender que a dinâmica do mercado torna o mundo um objeto particular passível de ser valorado. Em tal dinâmica, inclui-se os extremos da vida humana, de forma que, os efeitos do poder econômico influenciam diretamente sobre o bem e o mal, a segurança e o risco, o acúmulo de riqueza e a miséria, entre o ter direitos e o não ter direitos.

Em suma, "o mercado, como é conhecido, se rege na liberdade do indivíduo e nos seus direitos: uma perfeita circularidade além da qual não é possível $<<$ pensar $>>$ de outra forma". ${ }^{37}$

Jesús Ballesteros afirma que a biotecnologia de melhoramento se apoia na redução do ser humano a informação em um duplo sentido: i- redução do corpo humano a genoma (sociobiologia); ii- reduçáo da mente a programa informático (software). Dessa

33 Ibidem. pp. 29-35.

34 Francis Bacon aponta para o fim da separaçáo entre ciência e técnica ao reconhecer que a ciência moderna é necessariamente, ao mesmo tempo, técnica, ou seja, poder-habilidade. Portanto, desenvolvimento científico e técnico estão indissoluvelmente ligados na dinâmica complexa das RDTS (pela Pesquisa e o Desenvolvimento Tecno Científicos). Nesse sentido, ver: HOTTOIS, Gilbert. Técnica. Tradução de Maria Vitoria Kessler. In: Monique Canto-Sperber (Org.). Dicionário de Ética e Filosofia Moral. 2. ed. São Leopoldo: Editora Unisinos, 2013. p. 1008.

35 Biotecnología, biolítica y posthumanismo. In: Biotecnología y Posthumanismo. Jesús Ballesteros; Encarnación Fernández. (Coord.). 1. ed. Editorial Aranzadi, 2007. p. 28.

36 BARCELlONA, Pietro. Le Passione Negate: Globalismo e Diritti Umani. Troina: Città Aperta Edizioni di Oasi Editrice, 2001. p. 16.

37 Ibidem. mesma página, traduçáo nossa. (il Mercato, com'è noto, si regge sulla libertà dell'individuo e sui suoi diritti: una perfetta circolarità oltre la quale non è possibile <<pensare >> altrimenti.). 
forma, ocorre a redução de todo ente a objeto de mercado e lucro. O interesse econômico, portanto, coisifica as relaçóes convertendo os seres humanos em mercadorias. ${ }^{38}$

Bernadette Bensaude-Vincent, por sua vez, ao refletir sobre tecnologia e o mundo natural, salienta que está no "coração" das micro e nanotecnologia se libertar dos limites da matéria, assim, explica que o objetivo de reduzir a matéria até transformá-la em "condensados" de informação entra em harmonia com o objetivo de vida imortal. Desse modo, os esforços para armazenar cada vez mais informaçóes em espaços menores correspondem aos esforços dos que visam afastar os efeitos do tempo sobre os corpos biológicos, resultando na libertação da matéria e do tempo por intermédio de um só projeto. ${ }^{39}$

A autora menciona como exemplo para ilustrar o potencial tecnológico para além das técnicas de aumento de performances esportivas, intelectuais, duração da vida, o "movimento transumanista”, surgido em 1980 nos Estados Unidos, que apregoa o objetivo de chegar à imortalidade. Ao citar esse movimento, a autora o define como:

Entusiasmados por uma mistura de euforia tecnológica - suscitada pelas promessas da biotecnologia e nanotecnologia - e pela confiança num futuro de regimes alimentares que garantam a saúde, eles propagam a ilusão de que seria possível afastar a morte indefinidamente, até chegando-se à sua eliminação completa. ${ }^{40}$

O potencial tecnológico e a busca por ultrapassar as barreiras naturais em prol da perfeição apresenta uma ameaça à dignidade da pessoa humana.

Conforme exposto no início deste estudo, o avanço da técnica levou à tecnologia. Com efeito, outrora a técnica era um meio (instrumento) para o homem chegar a determinado fim. Todavia, na atualidade, em muitos casos, técnica e natureza humana se confundem, dessa forma, o homem já não é o ente manipulador da técnica, pois se tornou também um meio (instrumento) da manipulação tecnológica.

Portanto, determinados resultados tecnológicos ao lado dos interesses de mercado ferem a liberdade dos indivíduos, a igualdade posto que "ao lado do direito à igualdade nasce o direito à diferença, nesses termos, "importa assegurar a igualdade com respeito à diversidade" ${ }^{\prime 1}$, assim como, a solidariedade que se caracteriza pela dependência mútua solidária que gera obrigaçóes de uns para com os outros. Em outras palavras, atingem as três geraçôes clássicas de direitos humanos fundamentais.

38 Biotecnología, biolítica y posthumanismo. In: Biotecnología y Posthumanismo. Jesús Ballesteros; Encarnación Fernández. (Coord.). 1. ed. Editorial Aranzadi, 2007. p. 44.

39 As Vertigens da Tecnociência: Moldar o Mundo Átomo por Átomo. Tradução de José Luiz Cazarotto. Sáo Paulo: Ideias e Letras, 2013. pp. 113-115.

40 Ibidem. p. 117.

41 PIOVESAN, Flávia. Direitos Humanos e o Direito Constitucional Internacional. 13. ed. São Paulo: Saraiva, 2012. p. 257. 
Considerando os direitos humanos fundamentais como base para proteção do humanismo, importa citar Norberto Bobbio ao aduzir que "já se apresentam novas exigências que só poderiam chamar-se de direitos de quarta geração, referentes aos efeitos cada vez mais traumáticos da pesquisa biológica, que permitirá manipulaçôes do patrimônio genético de cada indivíduo". ${ }^{42}$

Nessa linha, tratando pois, de uma provável quarta geração, Vladmir Oliveira da Silveira e Maria Mendez Rocasolano, afirmam que "é possível identificar um novo valor que concretiza a dignidade da pessoa humana para além da solidariedade: a ética, responsabilidade ou moralidade científica”. ${ }^{43}$

Os autores defendem a ética/responsabilidade científica como valor de proteção humana diante do atual desenvolvimento tecnológico em um sentido que ultrapassa a terceira geração de direitos humanos fundamentais, ou seja, o valor solidariedade.

Hans Jonas afirma que "a tecnologia assume um significado ético por causa do lugar central que ela agora ocupa subjetivamente nos fins da vida humana”. ${ }^{44}$

Em termos de ética, o autor prossegue sob o entendimento de que:

Ela tem de existir porque os homens agem, e a ética existe para ordenar suas ações e regular seu poder de agir. Sua existência é tanto mais necessária, portanto, quanto maiores forem os poderes do agir que ela tem de regular. Assim como deve estar adaptado à sua magnitude, o princípio ordenador também deve adaptar-se ao tipo de ação que se deve regular. Por isso, capacidades de ação de um novo tipo exigem novas regras da ética, e talvez mesmo uma ética de novo tipo. ${ }^{45}$

A ética, portanto, existe para guiar as açóes do homem, bem como, para regular seu poder de agir. De forma que quanto maior for esse poder de agir mais essencial se torna a regulação ética.

Desta feita, cumpre apontar de modo sucinto pontos relevantes para compreensão da ética.

Paul Ricoeur explica que os termos moral e ética (um vem do latim e o outro do grego) e concernem ao campo comum dos costumes. $\mathrm{O}$ autor esclarece que o ponto fixo do conceito de moral pode ser dividido em duas funções: a de apontar o plano das normas,

42 A Era dos Direitos. Tradução de Carlos Nelson Coutinho. Rio de Janeiro: Elsevier, 2004. p. 5.

43 Direitos Humanos: Conceitos, Significados e Funçóes. São Paulo: Saraiva, 2010. p. 182.

44 O Princípio Responsabilidade: Ensaio de uma Ética para a Civilização Tecnológica. Tradução de Marijane Lisboa, Luiz Barros Montez. Rio de Janeiro: Contraponto: Ed. PUC-Rio, 2006. p. Ibidem. p. 43.

45 Ibidem. pp. 65-66. 
ou seja, princípios do permitido/proibido e o sentimento de obrigação subjetiva de um sujeito com relação às normas. ${ }^{46}$

Quanto à ética o autor divide seu conceito em dois: o de ética anterior e ética posterior. Em suma, "a ética anterior aponta para o enraizamento das normas na vida e no desejo; a ética posterior tem em vista inserir as normas em situaçóes concretas". ${ }^{47}$

A ética anterior se refere a uma ética fundamental que parte da linha "subjetiva da obrigação moral: do sentimento de estar obrigado" que configura a ligação entre as normas e a vida. ${ }^{48}$ Em outras palavras, é possível compreender a ética anterior como uma ética geral que abrange as regras morais que orientam a vida humana de forma global para um “viver bem".

Dos princípios gerais da ética anterior decorre a ética posterior, ou melhor, éticas posteriores que são aplicadas nos espaços da "sabedoria prática" ${ }^{49}$ Assim, por um lado existe uma ética anterior/teórica e por outro uma ética posterior/prática.

Paul Ricoeur sustenta que "o único meio de dar visibilidade e legibilidade ao fundo primordial da ética é projetá-lo no plano pós-moral das éticas aplicadas". ${ }^{50}$ Nessa linha prossegue argumentando que:

fórmulas ainda gerais que distribuem o imperativo por uma pluralidade de esferas - persistência de si mesmo, solicitude para com o próximo, participação cidadã na soberania - só se tornam máximas concretas de ação quando retomadas, retrabalhadas, rearticuladas em éticas regionais e especiais, tais como ética médica, ética judiciária, ética dos negócios, ética do meio ambiente e assim por diante, numa enumeração aberta. ${ }^{51}$

Portanto, entende-se que a ética fundamental tem profunda realização no âmbito das éticas aplicadas, sob um plano pós-moral. Desta feita, os princípios gerais de ética são concretizados efetivamente quando são incorporados e, por vezes, adequados às éticas especiais, que podem ser amplamente elencadas.

A importância da ética aplicada, ao tratar situaçôes específicas recai sobre o contexto, à análise das consequências e à tomada de decisão. Cada área específica acaba por delimitar um objeto de investigação ética e busca definir os métodos próprios de análise. ${ }^{52}$

46 O Justo 2: Justiça e Verdade e Outros Estudos. Tradução de Ivone C. Benedetti. São Paulo: WMF Martins Fontes, 2008. p. 49.

47 Ibidem. p. 50.

48 Ibidem. p. 52.

49 Ibidem. p. 57.

50 Ibidem. mesma página.

51 Ibidem. pp. 58-59.

52 Ibidem. pp. 390-391. 
Nesse sentido, convém destacar a bioética que se trata de uma ética aplicada à biotecnologia, ou seja, uma ética que parte da ética geral/anterior para regular no plano pósmoral da sabedoria prática a biotecnologia.

Logo, cada área de aplicação ética determina seu objeto de investigação e as metodologias próprias de estudo. Destaca-se que, a ética aplicada "posterior" se fundamenta a partir dos princípios da ética fundamental "anterior" e em outros princípios fundamentais. Neste caso, os princípios são readequados à nova realidade a ser conduzida.

Tendo em vista tais conceitos, cumpre afirmar que a ética pode ser a base para uma releitura dos preceitos de direitos humanos fundamentais protetores da dignidade da pessoa humana em face das novidades tecnológicas que dependendo dos fins almejados podem reduzir o que hoje se conhece por humanismo.

\section{Conclusões}

Atualmente a tecnologia permite realizar muitos desejos de homens e mulheres, fornece respostas às limitaçóes e necessidades de outrora. Contudo, quando esse potencial chega a manipulação da natureza humana por meio da engenharia genética e melhoramento, eugenia, clonagem, entre outras práticas, é possível afirmar que se inicia uma ameaça a dignidade da pessoa humana.

Nesse sentido, a tecnologia entendida como autossuficiente para ditar seu próprio desenvolvimento causa preocupação, pois transforma o ser humano também em um meio de manipulação tecnológica.

$\mathrm{Na}$ dinâmica do desenvolvimento tecnológico estão também as ameaças, pois tecnologias de ponta que proporcionam benefícios ao bem-estar humano podem por outro lado ir muito além, ferindo os direitos humanos fundamentais conquistados sob árduas lutas ao longo do tempo - entre esses os direitos à vida, liberdade e igualdade.

Cumpre ressaltar, nesse ponto, que as ameaças à dignidade da pessoa humana ganham nova roupagem. Dessa forma, ao passo que surgem novas ameaças, a ciência do Direito deve incorporar novas ferramentas para cumprir com seu papel de tutelar a sociedade.

Para tanto, importa a afirmação de novos limites com base no ordenamento jurídico vigente, bem como por intermédio de uma releitura dos valores tradicionalmente consagrados de direitos humanos representados pelas geraçóes de liberdade, igualdade e solidariedade. Nessa linha, vale afirmar que tal releitura pode se dar pela abertura da ciência jurídica a ética, pois convém na atual conjuntura direcionar o agir tecnológico para o bem, promovendo, justiça, equilíbrio e segurança à sociedade. 


\section{Referências}

BALLESTEROS, Jesús; FERNÁNDEZ, Encarnación. (Coord.) Biotecnología y Posthumanismo. 1. ed. Editorial Aranzadi, 2007.

BARCELLONA, Pietro. Le Passione Negate: Globalismo e Diritti Umani. Troina: Città Aperta Edizioni di Oasi Editrice, 2001.

BAUMAN, Zygmunt. Modernidade Líquida. Tradução de Plínio Dentzien. Rio de Janeiro: Zahar, 2001.

BENSAUDE-VINCENT, Bernadette. As Vertigens da Tecnociência: Moldar o Mundo Átomo por Átomo. Tradução de José Luiz Cazarotto. São Paulo: Ideias e Letras, 2013.

BOBBIO, Norberto. A Era dos Direitos. Tradução de Carlos Nelson Coutinho. Rio de Janeiro: Elsevier, 2004.

CANTO-SPERBER, Monique (Org.). Dicionário de Ética e Filosofia Moral. Tradução de Ana Maria Ribeiro-Althoff. et al. 2. ed. São Leopoldo: Editora Unisinos, 2013.

COMPARATO, Fábio Konder. A afirmação histórica dos direitos humanos. São Paulo: Saraiva, 2008.

DI CIOMMO, Francesco. Evoluzione tecnologica e regole di responsabilitá civile. Napoli: Edizioni Scientifiche Italiane, 2003.

DONAS, Javier Bustamante. Los Derechos Humanos de Cuarta Generación y sus Implicaciones en la Sociedade Contemporânea. In: Los Derechos Humanos en Internet. ; et al. Madrid: Cideal, 2012.

HESPANHA, António Manuel. Cultura Jurídica Europeia: Síntese de um Milênio. Coimbra: Almedina, 2012.

JONAS, Hans. O Princípio Responsabilidade: Ensaio de uma Ética para a Civilização Tecnológica. Tradução de Marijane Lisboa, Luiz Barros Montez. Rio de Janeiro: Contraponto: Ed. PUC-Rio, 2006.

LAUREN, Paul Gordon. The Evolution of International Human Rights. Philadelphia: University of Pennsylvania, 2003.

NUNES, Rui. Gene Ética. Coimbra: Almedina, 2013.

PÉREZ LUÑO, Antonio Enrique. Los Derechos Humanos ante las Nuevas Tecnologias. In: Nuevas Tecnologías y Derechos Humanos. . Valencia: Tirant lo blanch, 2014

. Derechos Humanos, Estado de Derecho y Constitución. Madrid: Tecnos, 2010 . 
PIOVESAN, Flávia. Direitos Humanos e o Direito Constitucional Internacional. 13. ed. São Paulo: Saraiva, 2012.

QUEIROZ, Cristina. Direitos Fundamentais. Coimbra: Coimbra, 2010.

RICOEUR, Paul. O Justo 2: Justiça e Verdade e Outros Estudos. Tradução de Ivone C. Benedetti. São Paulo: WMF Martins Fontes, 2008.

SANDEL. Michael J. Contra a perfeição: ética na era da engenharia genética. Tradução de Ana Carolina Mesquita. 1. ed. Rio de Janeiro: Civilização Brasileira, 2013.

SARLET, Ingo Wolfgang. A eficácia dos direitos fundamentais. Porto Alegre: Livraria do Advogado, 2006.

SEVCENKO, Nicolau. A Corrida para o Século XXI - No Loop da Montanha-Russa. São Paulo: Companhia das Letras, 2001.

SILVEIRA, Vladmir Oliveira da; ROCASOLANO, Maria Mendez. Direitos Humanos: Conceitos, Significados e Funçóes. São Paulo: Saraiva, 2010. 